\title{
Strategi Komunikasi Pemasaran Kuliner Tradisional Di Cafe Gulo Jowo, Surakarta Melalui Media Instagram
}

\author{
Premierananda Yudistira*1 \\ Ratri Kusumaningtiyas ${ }^{2}$
}

\author{
1,2Ilmu Komunikasi, Fakultas Komunikasi dan Informatika, Universitas Muhammadiyah Surakarta, \\ Indonesia \\ *e-mail: premieranandaa@gmail.com ${ }^{1}$, Amenouzume3@gmail.com $^{2}$
}

(Naskah masuk : 26 April 2021, Revisi-1 : 12 Mei 2021, Revisi-2 : 20 Mei 2021, Publikasi : 25 Mei 2021)

\begin{abstract}
Abstrak
Makanan tradisional merupakan warisan budaya yang pada saat ini sudah sangat jarang ditemukan. Banyak orang beranggapan bahwa makanan tradisional adalah panganan yang sudah ketinggalan zaman, oleh sebab itu perlu adanya strategi komunikasi pemasaran agar masyarakat tetap dapat mengenal dan menikmati kuliner tradisional. Tujuan dari penelitian ini adalah untuk mengetahui Bagaimana strategi komunikasi pemasaran kuliner tradisional di Cafe Gulo Jowo, melalui media Instagram. Penelitian ini merupakan jenis penelitian kualitatif deskriptif. Metode pengumpulan data yang digunakan dalam penelitian ini yaitu observasi, dokumentasi dan wawancara. Hasil dari penelitian ini menunjukkan bahwa strategi komunikasi pemasaran kuliner tradisional di Cafe Gulo Jowo, surakarta melalui media instagram dilakukan dengan 5 konsep, yaitu strategi komunikasi pemasaran yang meliputi Advertising, Sales promotion, Public relation and publicity, Personal selling dan Direct marketing. Cafe Gulo Jowo berupaya untuk mengiklankan produknya melalui akun-akun instagram yang memberikan informasi mengenai event atau seputar kuliner di Kota Solo. Kemudian Cafe Gulo Jowo juga menyampaikan informasi melalui Instagram Story. Pada aktivitas penjualan personal, semua karyawan di Cafe Gulo Jowo dituntut untuk selalu ramah kepada pelanggannya untuk menjaga kedekatan secara emosional. Dalam melakukan aktivitas pemasaran langsung, pihak Cafe Gulo Jowo mencantumkan informasi berupa nomor telepon, alamat serta Aplikasi Go-food di beranda dan bio Instagram. Sosial media adalah sarana bagi penjual untuk memasarkan usahannya, bagi pelaku usaha makanan tradisional dapat menggunakan instagram agar makanan tradisonal dapat digemari banyak orang.
\end{abstract}

Kata kunci: Instagram, Pemasaran, Strategi komunikasi.

\begin{abstract}
Traditional food is a cultural heritage which is now rarely found. This is because of the assumption that traditional food is an outdated snack. Therefore it is necessary to have a marketing communication strategy so that people can still get to know and enjoy traditional culinary. The purpose of this study was to determine how the traditional culinary marketing communication strategy at Cafe Gulo Jowo, through the media of Instagram. This research is a descriptive qualitative research. Data collection methods used in this study are observation, documentation and interviews. The results of this study indicate that the traditional culinary marketing communication strategy at Cafe Gulo Jowo, Surakarta through Instagram media is carried out with the concept of 5 concepts of marketing communication strategies which include advertising, sales promotion, public relations and publicity, personal selling and direct marketing. Cafe Gulo Jowo seeks to advertise its products through Instagram accounts that provide information about events or about culinary in Solo. Then Cafe Gulo Jowo also conveyed information through Instagram Story. In personal selling activities, all employees at Cafe Gulo Jowo are required to always be friendly to their customers to maintain emotional closeness. Then in carrying out direct marketing activities, Cafe Gulo Jowo includes information in the form of telephone numbers, addresses and Go-food applications on the homepage and Instagram bio. Social media is a means for sellers to market their business, for traditional food businesses can use Instagram so that traditional food can be favored by many people.
\end{abstract}

Keywords: Communication strategy, Instagram, Marketing.

\section{PENDAHULUAN}

Komunikasi pemasaran adalah suatu kegiatan komunikasi yang tujuannya menyampaikan pesan ke konsumen memanfaatkan variasi media, harapannya agar komunikasi membawa perubahan pengetahuan, sikap, dan tindakan sesuai yang diinginkan (Kennedy dan 
Soemanagara, 2011). Todorova (2015) menjelaskan bahwa komunikasi pemasaran adalah suatu ukuran, teknik dan metode dimana informasi tentang barang, jasa atau suatu perusahaan untuk mencapai penggunanya. Peran komunikasi pemasaran sangat vital bagi perusahaan sebagai sarana pencitraan (image) atas suatu merek tertentu. Melalui komunikasi pemasaran, kesadaran konsumen terhadap produk perusahaan dapat dikembangkan, dengan demikian konsumen mengenal produk yang ditawarkan. (Madengke, et al., 2017).

Dalam kegiatan pemasaran, komunikasi menjadi hal yang harus diperhatikan.kegiatan pemasaran dapat berlangsung dan mencapai hasil yang diinginkan melalui komunikasi. Di level dasar, komunikasi dilakukan untuk menginformasikan sehingga mendapat konsumen potensial untuk mengetahui keberadaan produk yang ditawarkan. Melalui komunikasi konsumen saat ini maupun konsumen potensial untuk menjalin hubungan pertukaran (Nurhidayah, 2014). Komunikasi juga sebagai pengingat konsumen akan produk yang pernah diperjualbelikan. Peran komunikasi lainnya adalah membedakan produk dengan produk perusahaan lain. Dengan demikian dengan komunikasi didapatkan segmentasi pasar yang lebih luas (Mahfoedz, 2015).

Perkembangan teknologi yang terjadi saat ini, berpengaruh besar terhadap komunikasi pemasaran antara perusahaan dengan konsumen. Menurut Abyad (2017) Komunikasi pemasaran dengan media internet mendatangkan keuntungan di berbagai bidang. Proses pemasaran via internet membuat konsumen lebih mudah memperoleh barang yang mereka inginkan. Contoh komunikasi pemasaran melalui media internet adalah penggunaan sosial media. Sangadji dan Sopiah (2013) menyatakan bahwa dahulu konsep pemasaran lebih berorientasi pada penjualan. Konsep ini lebih terfokus pada kemampuan perusahaan untuk menjual produk sebanyakbanyaknya. Namun saat ini, dengan hadirnya media sosial mengakibatkan strategi berkomunikasi kepada konsumen mengalami perubahan yang efesien, hal ini dikarenakan media sosial merupakan sarana promosi yang sangat efektif untuk memperkenalkan produk-produk perusahaan yang dapat diakses oleh siapa saja, kapan saja dan dimana saja, sehingga dapat mencapai jaringan yang lebih luas. Hal ini menjadikan media sosial sebagai salah satu cara media terbaik untuk menjangkau luasnya pasar sasaran.

Media sosial mempunyai sejumlah manfaat sendiri dibandingkan dengan promosi lainnya seperti media konvensional. Misalnya, media sosial lebih mudah digunakan dibandingkan media konvensional seperti televisi dan radio. Selain itu, dalam melakukan kegiatan pemasaran sosial media dapat dilakukan dimana saja dan kapan saja, berbeda dengan media konvensional membutuhkan waktu lebih banyak karena faktor prosedural. Menurut Tjiptono (2019) Media sosial mempunyai beberapa fungsi utama dalam dunia bisnis. Yang pertama, sosial media sebagai wadah untuk konsumen berinteraksi dengan penjual. Lalu yang kedua, sosial media sebagai sarana antara konsumen satu dengan konsumen lainnya saling berinteraksi serta sebagai media komunikasi dipergunakan sebagai sarana memproduksi, mendistribusikan, menyebarkan dan menyampaikan informasi mengenai suatu produk. Menurut Yuviana (2018) Dibandingkan dengan media sosial lain, instagram menjadi yang paling digemari. Hal ini dikarenakan instagram instagram sebagai aplikasi microbloging fungsi utamanya untuk mengunduh foto. Tidak hanya itu Instagram dapat dimanfaatkan untuk mendistribusikan, menyampaikan, dan menyebarkan informasi mengenai produk tertentu baik kuliner, fashion maupun jasa.

Kuliner adalah salah satu jenis usaha yang bergerak di bidang makanan, dimana perkembangannya sangat cepat mengikuti perkembangan jaman. Istilah kuliner diambil dari bahasa Inggris "culinary" yang berarti berhubungan dengan masakan atau dapur. Kuliner menjadi bagian dari gaya hidup yang tak terpisahkan dari kehidupan sehari-hari. Semua orang membutuhkan makanan dalam kehidupan mereka sehari-hari, entah makanan sederhana hingga mewah. Hal tersebut memerlukan teknik pengolahan yang menarik \& tepat (Lazuardi, et.all. 2015). Pengusaha bisnis kuliner mulai berlomba menciptakan menu baru agar konsumen tertarik untuk datang dan mencicipinya. Dengan semakin banyak orang yang menjalankan usaha kuliner, maka persaingan pun juga terus meningkat. Dampak yang ditimbulkan adalah tergesernya kuliner tradisional yang merupakan wujud budaya kedaerahan yang mencerminkan potensi alam daerah masing-masing. Karena faktor perubahan zaman, makanan tradisional semakin sulit ditemukan. Bagi sebagian masyarakat makanan tradisional dianggap ketinggalan zaman, sehingga mereka

JISHI 
mulai beralih pada makanan modern, padahal makanan tradisional merupakan warisan nenek moyang yang keberadaannya perlu dilestarikan. (Kusmaningttyas, 2013). Kota Surakarta adalah salah satu wilayah yang memiliki banyak variasi makanan kuliner yang kini mulai ditinggalkan.

Kota Surakarta atau yang dikenal juga dengan sebutan kota Solo merupakan kota wisata sekaligus budaya yang memiliki slogan "Solo The Spirit of Java". Kota ini mampu menjadi trend setter bagi kota/kabupaten lainnya dalam bidang ekonomi dan sosial budaya. Solo tidak hanya memiliki berbagai makanan khas daerah seperti timlo, tengkleng, tumpeng, nasi liwet, dan gudeg yang masih ada hingga saat ini, namun juga ada beberapa kuliner tradisional solo yang hampir punah diantaranya yaitu lejongan, sego pecel abang, kembang gula, es kapal, dan cabuk rambak. Minat kuliner tradisional yang berkurang serta minimnya promosi membuat kuliner khas Kota Solo tersebut tenggelam. Sehingga perlu adanya strategi komunikasi yang menjadi media promosi serta pengenalan produk terutama para remaja yang belum atau pernah mencicipi makanan tradisional tersebut. Sehingga kuliner tradisional yang merupakan ciri serta warisan daerah dapat tetap terjaga.

Gulo Jowo Solo merupakan salah satu Cafe yang menawarkan aneka jajanan tradisional khas Nusantara. Cafe Gulo Jowo berlokasi di Jl. Museum No.32, Sriwedari, Kec. Laweyan, Kota Surakarta dan cabang II berada di Pagedongan, Kleco Kota Solo. Cafe Gulo Jowo buka dari jam 7 hingga 11 malam. Cafe Gulo Jowo menawarkan berbagai menu tradisional Kota Solo yang jarang di temui pada saat ini seperti bakmi toprak, tahu acar, nasi timlo solo, dan sop ndeso. Selain itu Cafe Gulo Jowo juga menjual berbagai aneka jajanan tradisional lain seperti semar mendem, ketan mete, ronde, angsle, bajigur, hingga beras kencur. Sebagai salah satu usaha yang bergerak pada bidang kuliner tradisional yang berbeda tentunya perlu dibutuhkan stategi komunikasi yang mampu menjadi media pengenalan kuliner tradisional. Terlebih pada saat ini makanan tradisional semakin tidak populer dan kalah oleh pengaruh makanan luar yang berasal dari negara lain seperti Chinese Food, Japanese Food, Korean Food dan Western Food. Untuk itu perlu adanya strategi komunikasi yang mampu menjadi media pengenalan kuliner tradisional.

Hasil peneltian yang dilakukan oleh Kirana (2017) menemukan bahwa Kegiatan IMC telah dilakukan pihak Gulo Jowo, mulai dari menentukan strategi dan target market, serta pemilihan kegiatan promosi seperti beriklanan dengan menggunakan stiker dan juga pemanfaatan aplikasi delivery online, promosi penjualan dengan pemberian promo dan juga voucher, penjualan personal dilakukan dengan mengikuti kegiatan bazar makanan, dan juga hubungan masyarakat yang dilakukan dengan aktif menjadi sponsor event musik di kota Solo, dan peliputan beberapa stasiun Televisi nasional, Radio dan juga media cetak koran. Namun masih ada beberapa hal yang juga harus dievaluasi guna lebih meningkatkan kegiatan promosi tersebut agar pesan dapat tersampaikan sesuai dengan target market Gulo Jowo. Melalui penelitian tersebut, menjadi dasar dalam menganalisis penggunaan IMC pada Gulo Jowo sebagai strategi komunikasi pemasaran dalam menentukan segmentasi dan target market serta pengaplikasian elemen strategi komunikasi melalui media sosial.

Hasil penelitian Nushan (2019) mengungkapkan bahwa strategi komunikasi pemasaran Popolo Coffee lewat media sosial instagram cukup efektif dan efisien dalam menarik minat kalangan generasi milenial untuk mengunjungi langsung ke café tersebut. Disamping penggunaan media Instagram meningkatkan partisipasi netizen untuk aktif dalam mempromosikan Popolo Coffee, hal ini menjadikan Popolo Coffee pilihan destinasi para generasi milenial. Persamaan penelitian tersebut adalah sama-sama menganalisis strategi komunikasi pemasaran melalui media sosial instagram pada usaha kuliner. Perbedaannya yaitu penelitian tersebut menganalisis strategi komunikasi pemasaran melalui media sosial instagram di Popolo Coffee. Sedangkan penelitian ini hanya menganalis strategi komunikasi melalui media sosial instagram yang dilakukan oleh pihak Cafe Gulo Jowo.

Kuliner tradisional semakin mengalami kemunduran, hal ini dapat dilihat dari banyaknya generasi muda yang tidak familiar dengan kuliner tradisional padahal Kuliner tradisional penting untuk dijaga dan dilestarikan keberadaanya sebagai warisan nenek moyang. Adapun salah satu hal yang menjadi penyebabnya yaitu kurangnya apresiasi dan pengenalan terhadap warisan tradisi dan sejarah kebudayaan kuliner. Berkembangnya informasi dan minat dan gaya hidup 
masyarakat modern yang semakin selektif sekaligus konsumtif, menuntut adanya fasilitas baru, inovatif dan memenuhi standar. Berdasarkan latar belakang diatas maka penulis tertarik untuk mengetahui bagaimana strategi yang digunakan oleh Cafe Gulo Jowo untuk mengenalkan kuliner tradisional yang saat ini mulai tergeser oleh banyak makanan yang berasal dari negara lain. Tujuan penelitian ini adalah untuk mengetahui Bagaimanakah strategi komunikasi pemasaran kuliner tradisional di Cafe Gulo Jowo, Surakarta melalui media Instagram.

\section{METODE}

Penelitian ini merupakan jenis penelitian kualitatif dengan desain penelitian deskriptif. Menurut Sugiyono (2012) penelitian kualitatif deskriptif digunakan untuk meneliti suatu kondisi objek alamiah, dalam hal ini peneliti sebagai instrumen kunci, adapun teknik pengumpulan data dengan triangulasi, analisis data bersifat induktif atau kualitatif, sedangkan hasil penelitian kualitatif lebih menekankan makna daripada generalisasi. Pada penelitian ini metode deskriptif digunakan untuk mendeskripsikan strategi komunikasi pemasaran kuliner tradisional di Cafe Gulo Jowo, Surakarta melalui media Instagram.

Data yang digunakan pada penelitian ini terdiri dari dua jenis data yaitu data primer dan data sekunder. Data Primer, yaitu data yang langsung dikumpulkan oleh peneliti dari subyek penelitian atau lapangan. Diantaranya diperoleh langsung dari hasil wawancara dengan narasumber. Narasumber pada penelitian ini adalah pihak dari Cafe Gulo Jowo, Surakarta. Data Sekunder, yaitu informasi yang dikumpulkan peneliti melalui pihak lain. Menurut Sugiyono (2012) adalah Sumber data yang tidak langsung memberikan data kepada pengumpul data, misalnya melalui orang lain atau melalui dokumen. Data sekunder ini digunakan untuk melengkapi data primer. Dalam penelitian ini sumber data primer didapatkan dari dokumendokumen, jurnal-jurnal, serta literature yang sesuai dengan kajian penelitian ini.

Adapun teknik-teknik yang digunakan untuk mengumpulkan data adalah a) Wawancara yaitu dimana dua orang bertemu, bertukar informasi dan ide lewat proses tanya jawab, hingga makna dapat dikonstruksikan kedalam suatu topik tertentu (Sugiyono, 2012). Dalam penelitian ini, peneliti melakukan teknik wawancara mendalam (indepth interview) kepada informan menggunakan interview guide agar wawancara lebih terarah dan tidak keluar dari pokok penelitian. Informan atau narasumber yang dimaksud adalah yang memiliki kaitan dengan strategi pemasaran yang oleh pihak Cafe Gulo Jowo, Surakarta melalui media Instagram. Adapun penentuan informan dilakukan dengan teknik Purposive sampling. Purposive sampling yaitu teknik menentukan sampel melalui kriteria tertentu (Sugiyono, 2010) kriteria infroman dalam penelitian ini yaitu karyawan yang berkerja di Cafe Gulo Jowo Surakarta dan bertugas di bagian Head Marketing Comunication. b) Observasi. Menurut Nawawi (dalam Afifuddin dan Beni, 2012), observasi adalah pencatatan dan pengamatan pada unsur-unsur yang tampak dalam suatu gejala dalam objek penelitian. Dalam penelitian ini, peneliti akan menggunakan teknik observasi nonpartisipan dimana peneliti tidak terlibat dan hanya sebagai pengamat independen. c) Dokumentasi. Dokumen merupakan catatan peristiwa yang sudah berlalu. Dokumen bisa berbentuk tulisan, gambar, atau karya-karya monumental dari seseorang (Sugiyono, 2012). Teknik ini dilakukan untuk mengumpulkan data pendukung yang dapat memperjelas data utama.

Menurut Sutopo (2010) analisa data memiliki beberapa tahapan, yaitu memberi nomor halaman, mengurutkan kategori koding, merancang penomoran unit-unitnya, dan menyalinnya. Miles dan Huberman (dalam Sutopo, 2010) menjelaskan bahwa ada tiga kegiatan utama dalam analisis data kualitatif yang terjadi secara bersamaan dan saling berkaitan, yaitu reduksi data, penyajian data dan penarikan kesimpulan atau verifikasi. Setelah data dianalisis maka untuk menguji keabsahan data digunakan analisis triangulasi. Melalui analisis triangulasi, jawaban subjek dianalisis dengan meneliti kebenaran melalui data empiris (sumber data lain) yang tersedia. Adapun analisis triangulasi yang digunakan dalam penelitian ini adalah triangulasi sumber. Data yang sudah dikumpulkan lalu diklasifikasikan dalam kategori-kategori tertentu. Proses kategorisasi dilakukan dengan mempertimbangkan aspek kevalidan, kompetensi subjek penelitian, tingkat autentisitasnya dan melakukan triangulasi sumber data. Kemudian dilakukan analisis data hingga mendapatkan kesimpulan. 


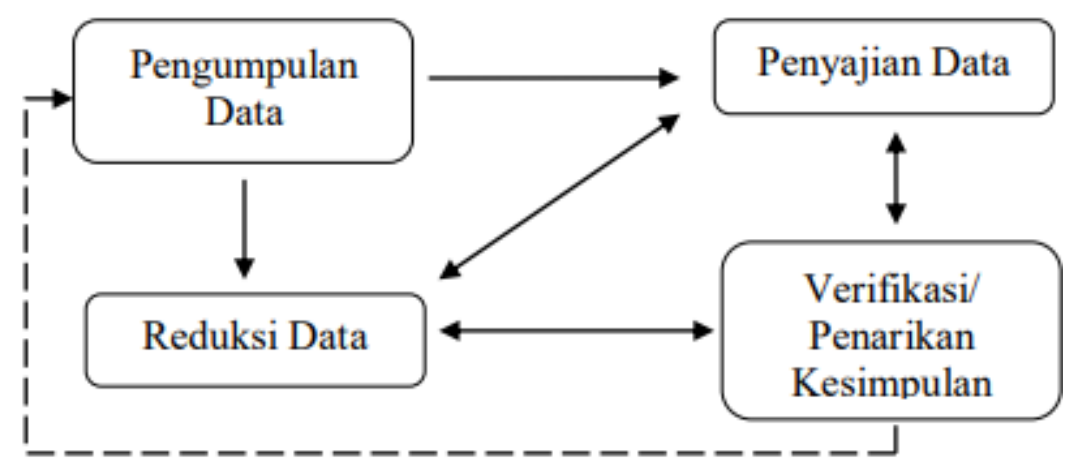

Gambar 1. Skema Analisis Data Kualitatif

\section{HASIL DAN PEMBAHASAN}

Komunikasi pemasaran adalah suatu usaha untuk menyampaikan pesan kepada konsumen terutama konsumen sasaran tentang eksistensi suatu produk di pasar. Adapun konsep yang umum digunakan untuk menyampaikan pesan adalah bauran promosi (promotional mix). Kotler \& Kevin (2013) mengungkapkan bahwa ada 5 perangkat utama unsur bauran promosi (promotion mix) yaitu: Advertising, Sales promotion, Public relation and publicity, Personal selling dan Direct marketing. Berdasarkan hasil penelitian diketahui bahwa strategi komunikasi pemasaran yang dilakukan oleh Cafe Gulo Jowo, Surakarta melalui media Instagram adalah sebagai berikut:

\subsection{Periklanan (Advertising)}

Periklanan (Advertising) adalah seluruh penyajian non personal, promosi ide-ide, promosi produk atau jasa yang dilakukan sponsor tertentu yang dibayar. Berdasarkan hasil penelitian diketahui bahwa untuk periklanan, Cafe Gulo Jowo mengiklankan produknya melalui akun-akun instagram yang memberikan informasi mengenai event atau seputar kuliner di Kota Solo. Selain itu, Cafe Gulo Jowo juga aktif dalam membuat Instagram Story (Instastory) untuk mengiklankan produknya. Seperti pada hasil wawancara berikut ini:

"Kalau untuk iklan, kita biasanya iklan lewat akun instagram yang seputar kuliner

di Kota Solo, atau kadang juga Informasi seputar solo. Kadang juga kita bikin

Instastory setiap hari kadang 3 atau 4 kali Instastory" (Tommi, 10 Juli 2020)

Berdasarkan hasil wawancara diketahui bahwa berkaitan dengan aktivitas periklanan, Cafe Gulo Jowo berupaya untuk mengiklankan produknya melalui akun-akun instagram yang memberikan informasi mengenai event atau seputar kuliner di Kota Solo. Selain itu, Cafe Gulo Jowo juga aktif dalam membuat Instagram Story (Instastory) untuk mengiklankan produknya 3 atau 4 kali dalam sehari. Hasil penelitian Lailatus (2017) menemukan bahwa periklanan produk yang dilakukan melalui postingan di Instagram berupa foto dan video dapat menarik perhatian para pengguna Instagram dan semakin sering di posting dan dilihat maka akhirnya akan mencapai kesadaran tentang suatu produk. Kemudian berdasarkan hasil wawacara dengan narasumber kedua diketahui bahwa alasan Cafe Gulo Jowo menggunakan media instragram untuk mengiklankan produknya karena instagram merupakan media yang mudah dan mudah. Seperti pada hasil wawancara berikut ini:

"Instagram itu kan mudah dan murah ya. Mudah dalam artian sangat simpel untuk digunakan di segala kalangan. Sudah banyak yang menggunakan instagram dari anak kecil, remaja hingga ibu-ibu dan bapak bapak. Jadi sangat cocok untuk melakukan pemasaran di instagram karena memang media sosial ini di minati oleh semua kalangan. (Sutikno, 12 September 2020)

Berdasarkan hasil wawancara di atas diketahui bahwa alasan Cafe Gulo Jowo menggunakan media Instragram dalam melakukan periklanan dikarenakan, Instagram 
merupakan media yang mudah dan murah untuk digunakan. Buniac \& Lundberg (2016) mengungkapkan bahwa perusahaan banyak menggunakan instagram untuk melakukan pemasaran produknya, alasannya karena instagram lebih mudah dan murah dalam mendukung pemasaran. Bentuk kemudahan tersebut diantaranya cara share ke berbagai media sosial lain dengan demikian pemasaran produk tersebar dengan lebih mudah. Selain itu hampir semua kalangan juga menggunakan Instagram sehingga sangat sesuai untuk media periklanan.

Kemudian berdasarkan hasil observasi juga diketahui bahwa hasil dari kegiatan pengiklanan yang dilakukan melalui akun-akun instagram tersebut menunjukkan bahwa banyak respon dari pengguna akun instagram yang melihat postingan yang dibagikan. Kegiatan pengiklanan Cafe Gulo Jowo dilakukan dengan cara membuat Instastory untuk mengiklankan produknya 3 atau 4 kali dalam sehari. Seperti pada gambar berikut ini:
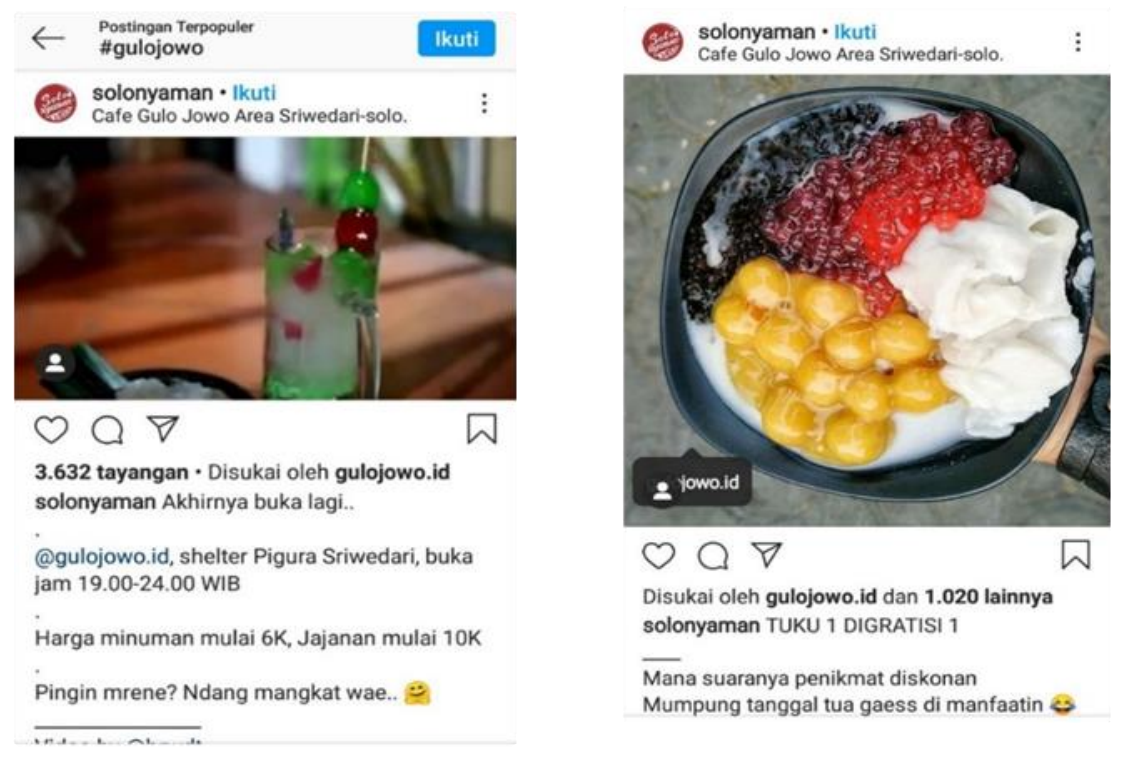

Gambar 2. Periklanan Cafe Gulo Jowo Melalui Akun Instagram Informasi Sekitar Solo

Hasil penelitian Lailatus (2017) menemukan bahwa semakin sering suatu produk di posting dan dilihat, maka produk tersebut akan semakin sering dilihat oleh pengguna Instagram sehingga pada akhirnya akan mencapai kesadaran dan ketertarikan tentang suatu produk.

\subsection{Promosi Penjualan (Sales promotion)}

Promosi penjualan adalah cara untuk memperkenalkan produk kepada publik, dan dan mendekatkan konsumen dengan perusahaan dengan memperkuat aktivitas bisnis dan juga menjaga komunikasi kepada konsumen, sehingga konsumen menjadi loyal terhadap produk tersebut (Suryani, 2014). Tujuan dari promosi penjualan adalah untuk memperkenalkan produk, serta mendorong konsumen agar membeli produk. Berdasarkan hasil penelitian diketahui bahwa promosi penjualan yang dilakukan Cafe Gulo Jowo dilakukan melalui Instastory serta sorotan yang terdapat dalam halaman akun instagram Cafe Gulo Jowo. Seperti hasil wawancara berikut ini:

"Untuk promosi, kita selalu posting lewat Instastory, jadi biar bisa banyak orang yang liat promosinya, selain itu promosi yang kita berikan biasanya juga ditaruh di sorotan. Jadi klo ada orang yang buka IG kita bisa liat kita ada promo apa gitu.. "(Tommi, 10 Juli 2020)

Berdasarkan hasil wawancara diketahui dalam aktivitas promosi penjualan melalui media sosial instagram, Cafe Gulo Jowo menyampaikanya informasi tersebut melalui Instagram Story (Instastory) untuk serta menjadikan Instagram Story (Instastory) tersebut menjadi sebuah sorotan pada halaman instagram @gulojowo.id sehingga dengan aktivitas tersebut, diharapkan orang mampu mengetahui mengenai promosi apa yang sedang diberikan oleh Cafe Gulo Jowo. Hal ini sejalan dengan pendapat Lovelock (2012) yang menjelaskan bahwa promosi penjualan 
memiliki tujuan untuk mempercepat keputusan membeli atau memotivasi pelanggan untuk mempercepat keputusan membeli atau memotivasi pelanggan untuk menggunakan jasa tertentu. Selain itu, berdasarkan hasil wawancara dengan narasumber kedua yang menyatakan bahwa promosi penjualan melalui instagram dilakukan dilakukan melalui fitur-fitur instagram. Seperti pada hasil wawancara berikut ini:

"Kalo ada promo, Kita biasanya pakai fitur instragram kayak postingan, instastory, sama sorotan. Jadi pelaggan yang melihat postingan tersebut bisa tertarik karena postingan yang kita share" (Sutikno, 12 September 2020)

Berdasarkan hasil wawancara dengan narasumber kedua diketahui bahwa Cafe Gulo Jowo menggunakan beberapa fitur yang dimiliki Instagram untuk melakukan promosi penjualan sehingga dapat menarik minat pelanggan untuk datang dan melakukan pembelian di Cafe Gulo Jowo. Hasil penelitian Buyer (2016) menemukan bahwa keterbukaan dan kredibilitas influencer dalam social media terhadap konsumennya juga sangat memiliki pengaruh social dan dapat membuat fenomena yang sukses. Berdasarkan hasil observasi diketahui bahwa biasanya fitur Instagram yang digunakan untuk melakukan promosi penjualan Cafe Gulo Jowo adalah fitur Instastory dan sorotan. Seperti pada gambar berikut ini:
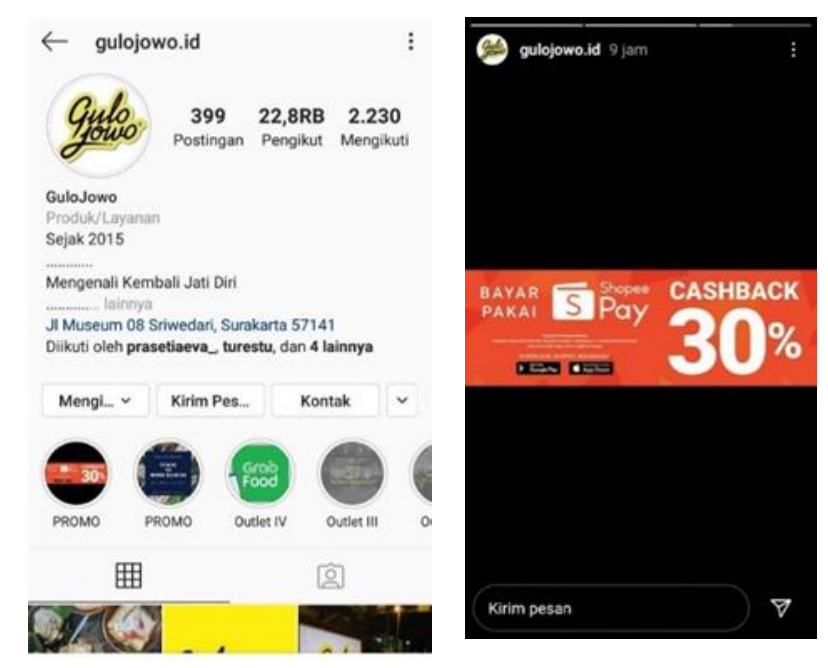

Gambar 3. Promosi penjualan Cafe Gulo Jowo melalui akun instragam

\subsection{Hubungan Masyarakat dan Publisitas (Public relation and publicity)}

Hubungan masyarakat dan publisitas terkait dengan program untuk mempromosikan dan melindungi kritera perusahaan atau produk individualnya. Shakeel \& Syed (2011) mengungkapkan bahwa dalam pelaksanaannya, komunikasi pemasaran tidak boleh terbatas pada pelanggan dan calon pelanggan, namun juga vendor, karyawan, industri terkait dan lingkungan eksternal yang secara langsung maupun tidak langsung terlibat di dalamnya. Berdasarkan hasil penelitian diketahui bahwa kegiatan hubungan masyarakat dan publisitas. Dilakukan dengan cara menjawab semua pertanyaan dan keluhan konsumen melalui media sosial instagram baik yang melalui komentar ataupun DM (Direct Massage). Seperti hasil wawancara berikut ini:

"Kalo untuk hubungan dengan konsumen, kita selalu menekankan kepada admin, untuk selalu bersikap ramah kepada para konsumen jadi klo kita ramah, kan mereka juga akan tertarik untuk datang kesini.." (Sutikno, 10 Juli 2020)

Berdasarkan hasil wawancara diketahui bahwa Cafe Gulo Jowo selalu berusaha memberikan pelayanan yang ramah dengan cara menjawab semua pertanyaan dari konsumen. Hal ini bertujuan agar para konsumen dan calon konsumen merasa tertarik untuk datang dan selalu merasa memiliki hubungan secara emosional dengan Cafe Gulo Jowo. Damjana \& Bruno (2012) menjelaskan bahwa produk dan layanan teknis yang kompleks, di mana beberapa orang terlibat di dalamnya serta adanya komunikasi interpersonal adalah cara terbaik menyajikan produk atau layanan tersebut. Puntoadi (2011) menjelaskan bahwa media sosial memberikan 
kesempatan untuk berinteraksi lebih dekat dengan konsumen. Hal ini dikarenakan media sosial menawarkan bentuk komunikasi yang lebih individual. Selain itu, penggunaan media sosial juga dapat digunakan oleh para pemasar untuk mengetahui kebiasaan konsumen mereka dan melakukan interaksi secara personal serta membangun keterikatan yang lebih dalam.

"Itu mas, kadang kita juga share postingan terus kita nge-tag, pelanggan yang ada dipostingan tersebut, atau klo gak biasanya malah kita repost postingan dari pelanggan sehingga mereka merasa dekat dengan kita." (Tommi, 12 September 2020)

Berdasarkan hasil wawancara diketahui bahwa Cafe Gulo Jowo terkadang memberikan tanda atau mencantumkan nama pelanggan yang menjadi follower serta terkadang melakukan repost foto postingan dari para pelanggan untuk menjaga kedekatan secara emosional antara pelanggan dengan Cafe Gulo Jowo. Seperti pada gambar hasil obervasi peneliti berikut ini:

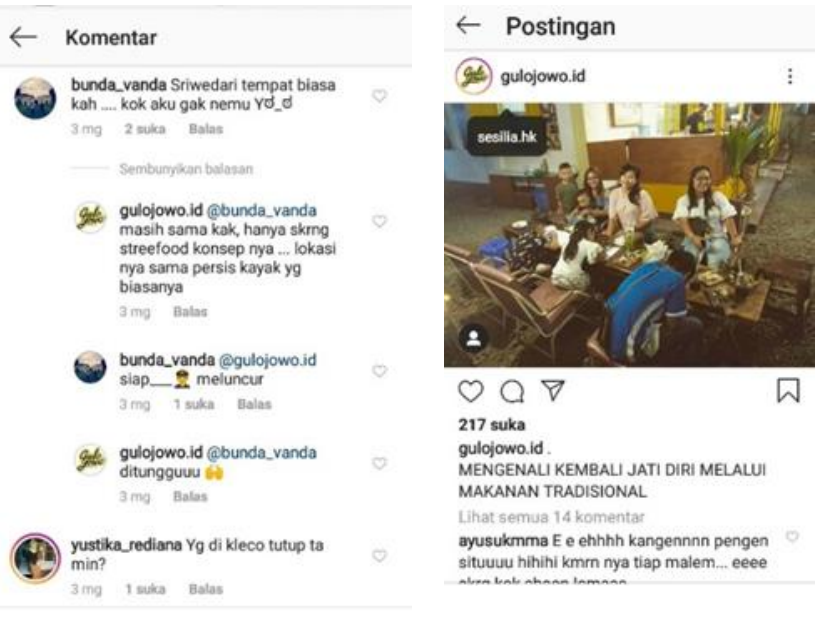

Gambar 4. Hubungan Masyarakat dan Publisitas Cafe Gulo Jowo melalui akun instragam

\subsection{Personal Selling}

Menurut Morissan (2012), penjualan personal merupakan bentuk komunikasi langsung antara penjual dan pembeli. Berdasarkan hasil wawancara diketahui bahwa Cafe Gulo Jowo memastikan bahwa karyawannya memberikan pelayanan terbaik untuk pelanggannya. Seperti hasil wawancara berikut ini:

"Oh..kalau itu kita biasanya selalu menegaskan kepada karyawan yang bekerja untuk bersikap ramah saat sedang memberikan pelayanan kepada pelanggan mas, jadi saat ada rapat evaluasi atau rapat bulanan kita biasanya juga gak lupa buat mengingatkan agar selalu bersikap ramah kepada pelanggan". (Sutikno, 10 Juli 2020)

Hal ini dipertegas oleh jawaban dari narasumber lainya, Tommi seperti pada hasil wawancara berikut ini:

"iya mas, kita selalu menegaskan kepada karyawan yang bekerja di outlet 1, 2,3 dan

4 untuk bersikap ramah saat melayani pelanggan" (Tommi, 10 Juli 2020).

Berdasarkan hasil wawancara diketahui bahwa dalam aktivitas penjualan personal, semua karyawan di Cafe Gulo Jowo dituntut untuk selalu ramah kepada pelanggannya. Hal ini dilakukan pelanggan merasa nyaman saat sedang berada di Cafe Gulo Jowo.

\subsection{Pemasaran langsung (Direct marketing)}

Pemasaran langsung yaitu aktivitas pemasaran melalui penggunaan telepon, faksimil, email, dan alat penghubung non personal lain untuk berkomunikasi secara langsung pelanggan tertentu dan calon pelanggan (Kotler \& Kevin, 2013). Berdasarkan hasil wawancara diketahui bahwa dalam melakukan pemasaran langsung, pihak Cafe Gulo Jowo mencantumkan informasi 
berupa nomor telepon, alamat serta Aplikasi Go-food di beranda dan bio Instagram. Seperti pada hasil wawancara berikut ini:

"Kalo di Instagram kita cantumkan kontak WA, sama alamatnya mas jadi misal ada yang mau pesen langsung lewat IG itu juga bisa, ada juga sorotan buat Gojeknya di situ." (Sutikno, 10 Juli 2020)

Suka \& Lubis (2019) menyatakan bahwa Pemasaran langsung adalah penggunaan saluran langsung konsumen untuk menjangkau dan mengirimkan barang dan jasa kepada pelanggan tanpa menggunakan perantara pemasaran. Berdasarkan hasil wawancara diketahui bahwa dalam aktivitas penjualan langsung yang dilakukan Cafe Gulo Jowo melalui Instagram, dilakukan dengan cara mencantumkan nomor Whatsapp (WA), alamat serta Aplikasi Go-food di beranda dan bio Instagram. Hal ini dilalukan agar memudahkan pelanggan dalam melakukan pembelian secara langsung.

"Kalo pemasaran langsung melalui Instragram, itu merupakan tugas admin ya, jadi selain menggunggah foto tugas admin itu juga harus melakukan follow up kepada para calon pembeli dan pelanggan untuk melakukan pembelian. " (Tommi, 10 Juli 2020)

Balakrishnan et. al (2014) menjelaskan bahwa penggunaan media social untuk mempromosikan suatu produk merupakan hal yang sangat penting bagi seorang pemasar. Hal ini dikarenakan penggunaan media sosial memiliki kelebihan dalam menjangkau segmen pasar usia muda dengan cara lebih cepat dan efisien. Berdasarkan hasil wawancara diketahui pemasaran langsung yang dilakukan oleh Cafe Gulo Jowo melalui instagram dilakukan oleh Admin yang mengelola akun instagram tersebut. Sehingga dapat disimpulkan bahwa admin merupakan kunci utama pemasaran langsung melalui instragram hal ini dikarenakan selain melakukan postingan, admin juga bertugas untuk melakukan follow up kepada para calon pembeli dan pelanggan untuk melakukan pembelian. Baik yang bagi para pelanggan yang melakukan chat lewat Direct massage (DM), komentar, atau nomor Whatsapp (WA). Seperti pada gambar berikut ini:
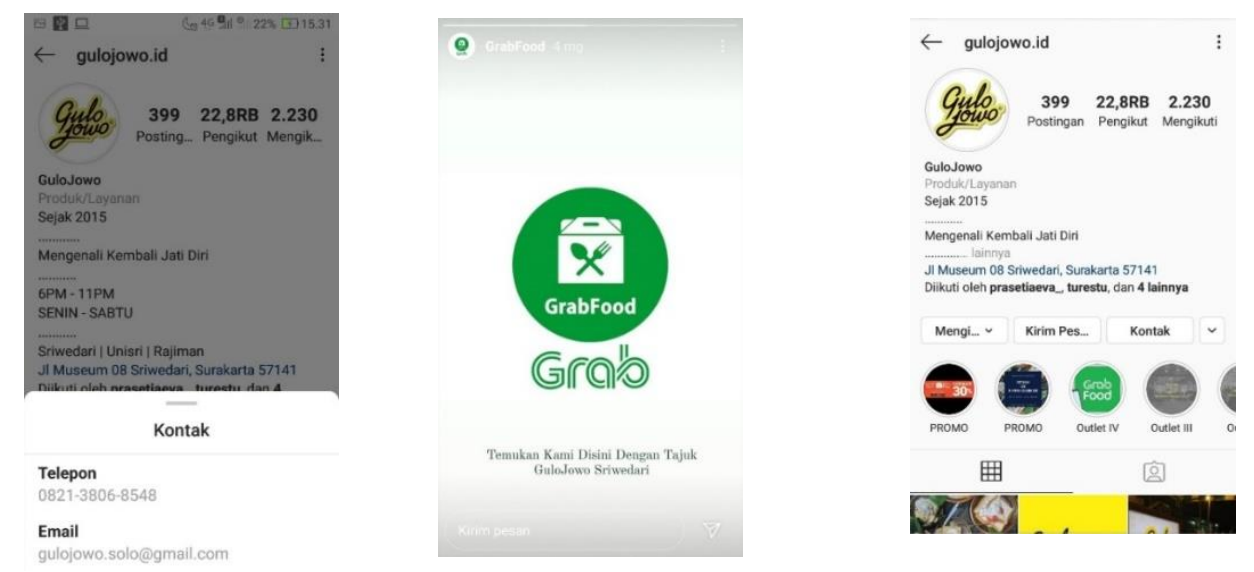

Gambar 5. Pemasaran langsung Cafe Gulo Jowo melalui akun instagram

\section{KESIMPULAN}

Berdasarkan hasil penelitian diketahui bahwa strategi komunikasi pemasaran kuliner tradisional di Cafe Gulo Jowo, surakarta melalui media instagram dilakukan dengan cara menerapkan konsep 5 konsep Strategi komunikasi pemasaran yang meliputi Advertising, Sales promotion, Public relation and publicity, Personal selling dan Direct marketing. Berkaitan dengan aktivitas periklanan (Advertising), Cafe Gulo Jowo berupaya untuk mengiklankan produknya melalui akun-akun instagram yang memberikan informasi mengenai event atau seputar kuliner di Kota Solo. Selain itu, Cafe Gulo Jowo juga aktif dalam membuat Instagram Story (Instastory) untuk mengiklankan produknya 3 atau 4 kali dalam sehari. Hal tersebut dilakukan karena instagram merupakan sarana yang mudah dan murah. Adapun hasil dari kegiatan pengiklanan 
yang dilakukan melalui akun-akun instagram tersebut menunjukkan bahwa banyak respon dari pengguna akun instagram yang melihat postingan yang dibagikan. Hal ini ditandai banyaknya akun instagram yang menyukai postingan yang dibagikan sebanyak 1.020 serta 3.632 orang yang menyaksikan video yang dibagikan.

Kemudian dalam aktivitas promosi penjualan (Sales promotion) melalui media sosial instagram, Cafe Gulo Jowo menyampaikanya informasi tersebut melalui Instagram Story (Instastory) untuk serta menjadikan Instagram Story (Instastory) tersebut menjadi sebuah sorotan pada halaman instagram @gulojowo.id sehingga dengan aktivitas tersebut, diharapkan orang mampu mengetahui mengenai promosi apa yang sedang diberikan oleh Cafe Gulo Jowo. Berdasarkan hasil wawancara diketahui bahwa Cafe Gulo Jowo selalu berusaha memberikan pelayanan yang ramah dengan cara menjawab semua pertanyaan dari konsumen. Hal ini bertujuan agar para konsumen dan calon konsumen merasa tertarik untuk datang dan selalu merasa memiliki hubungan secara emosional dengan Cafe Gulo Jowo.

Berdasarkan hasil wawancara diketahui bahwa dalam aktivitas penjualan personal (Personal selling), semua karyawan di Cafe Gulo Jowo dituntut untuk selalu ramah kepada pelanggannya selain itu Cafe Gulo Jowo juga melakukan repost atau menandai para pelanggan untuk menjaga kedekatan secara emosional. Kemudian dalam melakukan aktivitas pemasaran langsung (Direct marketing), pihak Cafe Gulo Jowo mencantumkan informasi berupa nomor telepon, alamat serta Aplikasi Go-food di beranda dan bio Instagram.

Berdasarkan kesimpulan di atas diharapkan penelitian selanjutnya dapat mengkaji lebih mendalam mengenai pengggunaan komunikasi pemasaran terutama melalui media sosial lainnya, tidak terbatas hanya di media instagram.

\section{DAFTAR PUSTAKA}

Abyad, Abdulrazak. (2017). Importance of Consumer Trust in e-commerce. Middle East Journal of Business. Vol 12.

Amalia, Asrinda, (2011). Perbandingan Strategi Komunikasi Pemasaran Pada Harian The Jakarta Post dan Harian Indonesian Observer Dalam Membangun Komunikasi Pemasaran Efektif. Jurnal Communication.Vol.1 : 70-77.

Suka, E. A., \& Lubis, S. (2018). Strategi Komunikasi Pemasaran Dalam Mempromosikan Produk Homemade Kefir di Kota Medan. Jurnal Network Media Vol: 2 (2).

Balakrsihnan, M., Irwan, D. dan Wong, J. Y. (2014). The Impact of Social Media Marketing Medium Toward Purchase Intention and Brand Loyalty Among Generation Y. Procedia-Social and Behavioral Sciences, vol.1 : 20-38.

Buinac, Ena and Lundberg, Jonatan. (2016). Instagram as a Marketing Tool (A Case Study about how comapanies Communicate their Brands on Social Media). Journal of Interactive Marketing 18: 38-52.

Damjana, J. dan Bruno, Z. (2012). The Model of Marketing Communications Effectiveness: Empirical Evidence From Slovenian Business-To-Business Practice. Journal of Business Economics and Management, Vol. 13 (4): 705-72

Dharmesta, Basu Swastha. (2014). Manajemen Pemasaran Modern. Yogyakarta: Liberty

Erika, D.S. (2012). Periklanan Dalam Media Baru. The Messenger, Vol. 4 (1):37-43

Jatmiko. (2014). Komunikasi Pemasaran Sebagai Strategi Memperluas Pasar. Skripsi. Universitas Esa Unggul, Jakarta

Kennedy, John E., \& R. Dermawan Soemanagara. (2011). Marketing Communication, Taktik \& Strategy. Jakarta : PT Buana Ilmu Populer, Kelompok Gramedia. 
Kirana, Prima. (2017). Strategi Komunikasi Pemasaran Terpadu (Studi Deskriptif Kualitatif Mengenai Aktivitas Komunikasi Pemasaran Terpadu Kafe Gulo Jowo Di Kota Solo). Naskah Publikasi. Fakultas Komunikasi Dan Informatika, Universitas Muhammadiyah Surakarta

Kotler dan Armstrong. (2014). Menajemen Pemasaran di Indonesia,Analisis. Perencanaan, Implementasi Dan Pengendalian. Jakarta: Salemba Empat.

Kottler, Philip dan Kevin Lane Keller.2009. Manajemen Pemasaran edisi 12 (jilid 2). Jakarta:PT Indeks

Lovelock, Christopher., et. al (2012). Pemasaran Jasa-Perspektif Indonesia. Ed. 7. Jil. 1. Terj. Dian Wulandari dan Devri Barnadi Putera. Jakarta: Erlangga

Lazuardi., et. all. (2015). Pembuatan dan karakterisasi bioplastik berbahan dasar kitosan dan pati singkong dengan plasticizer gliserol. Unesa Journal of Chemistry. 2 (3).

Machfoedz, M. (2015). Pengantar Pemasaran Modern. Akademi Manajemen Pemasaran YPKPN, Yogyakarta

Madengke, A., Sumampouw, H., \& Punuindoong, A. (2017). Pengaruh Komunikasi Pemasaran Terhadap Citra Perusahaan Jasa Penyewaan Alat Berat Pada PT. Buana Oto Mandiri. $\begin{array}{llll}\text { JURNAL ADMINISTRASI BISNIS } & \text { (JAB), }\end{array}$ doi:https://doi.org/10.35797/jab.0.0.2017.18377.\%p

Morissan, A.M. (2012). Periklanan Komunikasi Pemasaran Terpadu. Jakarta : Penerbit Kencana

Nasiha, Solehatun. (2010). Strategi Komunikasi Pemasaran terpadu (Integrated Marketing Communications) Dalam Mengkokohkan Brand Dagadu Djogja. Yogyakarta : Fakultas Ilmu Sosial dan Humaniora Universitas Islam Negeri Sunan Kalijaga

Nurhidayah, A.M.S. (2013). "Peran Komunikasi Interpersonal Wali Kelas Terhadap Motivasi Belajar Siswa," . Yogyakarta: UIN Sunan Kalijaga

Nushan, Musyaffa. (2019). Strategi Komunikasi Pemasaran Popolo Coffee Melalui Akun Instagram. Jurnal Diakom. Vol. 2 (2).

Paramitha, Cindy Rizal Putri, (2011). Analisis Faktor Pengaruh Promosi Berbasis Sosial Media Terhadap Keputusan Pembelian Pelanggan dalam Bidang Kuliner. Thesis. Ekonomi S-1, Fakultas Ekonomi Universitas Dipenogoro

Puntoadi, D. (2011). Menciptakan Penjualan Melalui Sosial Media. Jakarta: PT. Alex Komputindo.

Riyanto, A. (2015). "Pengertian Kuliner" [online]. Tersedia : http://kanalku.blogspot.in/2015/ 07/pengertian-kuliner.html?m=1 yang diakses 28 Februari 2020

Shakeel, R. dan Syed, I. (2011). Integrated Marketing Communication And Promotion. International Refereed Research Journal, Vol.2 (4) : 187

Sopiawati, Mira. (2010). Komunikasi Pemasaran dan Perilaku Pembelian (Studi Korelasi Antara Persepsi Konsumen Mengenai Aktivitas Komunikasi Pemasaran Terhadap Perilaku Pembelian Telkomsel Flash Unlimited Corporate Di Kalangan Dosen Universitas Sebelas Maret Surakarta Periode Januari Maret 2010) .Surakarta : Fakultas Ilmu Sosial dan Ilmu Politik Universitas Sebelas Maret Surakarta

Sugiyono. (2012). Metode Penelitian Pendidikan Pendekatan Kuantitatif, Kualitatif, dan R\&D. Bandung: Alfabeta

Sutopo. (2010). Terampil Mengolah Data Kualitatif Dengan NVIVO. Jakarta : Prenada Media Group.

Todorova, G. (2015). Marketing Communication Mix. Trakia Journal of Sciences, Vol. 13 (1) : 368374.

Wahyudi, Pontjo. (2014). Kuliner Jawa dalam Serat Centhini. Yogyakarta:BPNB DIY, Jateng dan Jatim

Yuviana, M. (2018). ). Strategi Komunikasi Jasa Iklan Instagram @solofoodgram Dalam Menghadapi Kompetitor. Naskah Publikasi. Fakultas Komunikasi Dan Informatika. Universitas Muhammadiyah Surakarta 
